\title{
Controlled traffic farming: an approach to minimize soil compaction and environmental impact on vegetable and other crops
}

\author{
Kumari Shubha*, Nongmaithem Raju Singh, Anirban Mukherjee, Aniruddha Maity and \\ Rachana Dubey
}

Mechanized farming for vegetable production has evolved as an integral part of commercial agriculture during the past few decades. As a first step towards mechanized farming the use of tractors in Indian agriculture has increased by 528\% during the period 1990-91 to 2018-19 from 0.15 to 0.8 million/year. Undoubtedly, use of such technologies has made vegetable as well as foodgrain production a profitable venture by easing land preparation, weed management and other intercultural operations, crop harvesting, etc. However, their continuous use in production fields has resulted in the substantial compaction of soil along the wheel lines of tractors and similar heavy machinery. Reports indicate a significant yield loss (13-73\%) owing to soil compaction because it restricts root penetrance into the soil, limiting nutrient and water uptake by the plants, and also potential water stagnation, which can limit the normal activities of respiring roots leading to retarded plant growth and root diseases. In this context, control traffic farming (CTF), which aims to reduce the area affected by the operation of heavy machinery that otherwise lead to soil compaction, brings a substantial value to the current global focus of sustainable and precision farming. CTF attempts to restrict the spatial movement of machinery wheels to fewer operation lanes during and across production cycles for a long time and allows specifically the undisturbed areas of soil for crop production. Research confirms a significant improvement in crop yield in different crop production systems worldwide and reduction in methane emission due to soil absorption (372-2100\%) compared to random traffic farming. In this article, we discuss the advantages of CTF in terms of root growth, nutrient mobilization and energy efficiency of the vegetable production system, and also argue on its scope in the Indian context, given the situation that no or only a few studies have been reported from the country.

Keywords: Controlled traffic farming, environmental impact, soil compaction, vegetables.

VEGETABLES are known to be highly sensitive to soil physical conditions such as soil compaction (SC). During the initial phase of crop growth, the effect of SC on root development and penetration into the soil is more pronounced than in the later stages ${ }^{1,2}$. However, interestingly, the initial phases of standard vegetable production

\footnotetext{
Kumari Shubha is in the Vegetable Science, Nongmaithem Raju Singh is in the Agroforestry, Anirban Mukherjee is in the Agricultural Extension and Rachana Dubey is in the Environmental Sciences, Division of Crop Research, ICAR-Research Complex for Eastern Region, Patna 800 014, India; Aniruddha Maity is in the Plant Breeding, Department of Soil and Crop Sciences, Texas A\&M University, College Station, Texas 77843, USA and Division of Seed Technology, ICAR-Indian Grassland and Fodder Research Institute, Near Pahuj Dam, Gwalior Road, Jhansi 284 003, India.

*For correspondence. (e-mail: shubha.veg@gmail.com)
}

strategies require heavy field operations such as tillage, planting, spraying and other intercultural and harvest operations in a timely manner, which necessitates the employment of powerful and heavy machinery in order to reduce the cost of labour and dependence on their availability. From an engineering perspective, pursuit of a higher operation efficiency and capacity of the farm equipment has gradually led to the increase in vehicle weight, which consequently resulted in traffic-induced SC. Given the reliance on heavy machinery in the current vegetable production systems, the problem of SC is difficult to avoid, especially during field preparation and harvest, because of the fact that a large number of vegetable crops are grown to the dry maturity stage and their harvesting usually occurs when the soil moisture conditions are naturally ideal for compaction. Besides this 
inherent limitation, the lack of integration of track gauge, large differences in the working width between individual machines and various harvesting methods using heavy machinery used for different vegetable crops have contributed to SC. In this context, controlled traffic farming (CTF), a crop production strategy in which the cropgrowing zone and traffic-lanes, i.e. the wheel movement areas are permanently and distinctly separated, promises great potential ${ }^{3}$. The crop-growing zone remains unaffected and maintains the soil physical properties, as a result of reduced bulk density and penetration resistance, which facilitates greater root development, maintenance of soil organic carbon (SOC), and improvement in water infiltration and hydraulic conductivity ${ }^{4}$. The traffic lanes are primarily maintained for the movement of machinery and surface drainage, and become more compacted by repeated operations which indeed improve the operational efficiency of the machinery when the soil is wet or irrigated ${ }^{5}$. Furthermore, the controlled traffic treatments have demonstrated improvements in the soil performance, and resulted in $20-60 \%$ fewer tillage operations compared to conventional production systems ${ }^{6}$.

Indian agriculture is limited by the severe problem of land fragmentation, where majority of the farmers have small or marginal land holdings. It may be argued that the use of CTF in such scenarios may result in economic setback to farmers and the farm mechanization process. However, states like Punjab, Haryana and western Uttar Pradesh, have gradually shifted to the heavy reliance on farm mechanization involving tractors, harvester, combiner, etc. It is evident from Figure 1 that the use of tractors for different farm operations has increased radically during the last few decades. Indian agriculture has witnessed an increase in the annual tractor procurement by $528 \%$ during the span of the last 26 years, viz. 1990-91 to $2018-19$ from 0.15 to 0.8 million/year (ref. 7). It is expected that the use of latest technologies for large-scale vegetable production, which primarily involves utilizing heavy machinery, will also increase in fulltime. In this situation, random traffic farming (RTF) is certainly

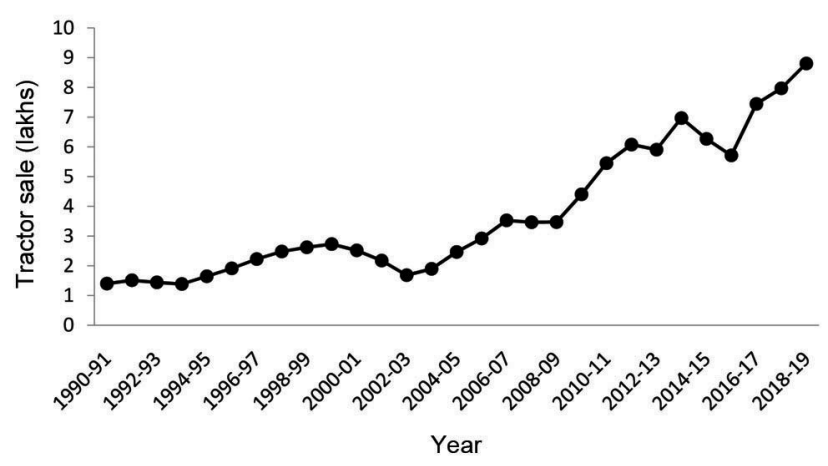

Figure 1. Trend of tractor sales during 1990-91 to 2018-19 in India. expected to adversely affect the soil aggregate formation leading to $\mathrm{SC}^{8,9}$. In this context it is important to mention that, unfortunately, most of the studies related to RTF/CTF have been confined to Australia, USA and a few other developed nations, but only a few or no studies have been reported from India. The use of CTF can provide extended opportunities for maximizing production efficiency by protecting the soil ecosystem and thereby increasing crop yield sustainably. Thus, in India, there exists a vast opportunity to explore the applicability and profitability of CTF with the aim to maximize the sustainability of production systems with a broad vision of conservation agriculture.

\section{Soil compaction creates multi-stress environments for vegetable production}

SC can be defined as "the process by which the soil particles are rearranged to decrease void space and bring them into closer contact with one another, thereby, increasing the bulk density ${ }^{10}$. SC alters the soil structural behaviour leading to low porosity along with less pore continuity and connectivity thereby affecting the chemical properties and microorganism biodiversity of the soil, and consequently the vegetable crop growth (Figure 2). $\mathrm{SC}$ favours the anaerobic condition of the root by restricting the soil gas diffusivity and water movement ${ }^{11}$. Root and tuber vegetables are highly sensitive to compaction as root growth becomes very slow or completely ceases when penetrometer resistance exceeds $2.0 \mathrm{MPa}$ (ref. 12). Orzolek ${ }^{13}$ compared the yield response of nine vegetable crops to SC and found an average yield reduction of $13 \%$ (watermelon) to 75\% (snapbean). Cabbage, cucumber and sweet corn showed yield reduction of $65 \%, 66 \%$ and $55 \%$ respectively, due to $\mathrm{SC}$.

Table 1 presents the negative impacts of SC on plant growth and development by disturbing the soil physicochemical and biological properties and gaseous exchanges. Studies have proved that the traffic-induced compaction mostly affects the upper layer of soil (top $\mathrm{SC}$ ) but it is also observed at extended depths (sub-SC; Figure 3). The sub-SC extends the degree of soil degradation and its alleviation is difficult due to unavailability of suitable technologies at greater soil depths, which worsens the problem ${ }^{9}$.

\section{Plant root physiological responses to $\mathrm{SC}$}

Prolonged water stagnation on the compacted soils adversely affects root metabolism, increases the incidence of root diseases ${ }^{14}$ and enhances activity of anaerobic denitrifying bacteria that further reduce nitrogen $(\mathrm{N})$ availability to the crops ${ }^{15}$. SC increases penetration resistance and reduces oxygen concentration in the soil ${ }^{16,17}$. Both result in reduction of root elongation rates, shallow 
GENERAL ARTICLES

Table 1. Negative impacts of soil compaction (SC) on plant growth and overall production

\begin{tabular}{|c|c|c|c|}
\hline Crops & Major findings & Place & Reference \\
\hline $\begin{array}{l}\text { Brussica oleracea L., Cucumis } \\
\text { sativus L., Phaseolus vulgaris L. } \\
\text { and Zea mays L. }\end{array}$ & $\begin{array}{l}\text { Drastic negative change ( } 73 \% \text { ) in the yield of B. oleracea } \mathrm{L} \text {. while } \\
\text { C. sativus } \mathrm{L} .(41 \%) \text {, Phaseolus vulgaris } \mathrm{L} .(49 \%) \text { and } Z \text {. mays } \\
\text { L. ( } 34 \%) \text { showed comparatively less reduction in yield. }\end{array}$ & USA & 8 \\
\hline Z. mays $\mathrm{L}$. & Yielded less $Z$. mays L. by affecting plant growth and soil properties. & Jordan & 9 \\
\hline $\begin{array}{l}\text { Raphanus sativus var. longipinnatus, } \\
\text { cv. 'Daikon', Brassica napus, cv. } \\
\text { 'Essex', and Secale cereale L., } \\
\text { cv. 'Wheeler' }\end{array}$ & $\begin{array}{l}\text { Lesser penetration of crop root in the soil. Among crops, the roots of } \\
R \text {. sativus var. longipinnatus, cv. 'Daikon had the highest level of } \\
\text { penetrance and could be recommended for biological tillage. }\end{array}$ & USA & 40 \\
\hline Cichorium intybus $\mathrm{L}$. & $\begin{array}{l}\text { Bulk density of greater than } 1.6 \mathrm{Mg} \mathrm{m}^{-3} \text { may cause harmful effect on soil } \\
\text { microbial activities. Interestingly, carbon mineralization rate showed } \\
\text { significant changes when soil was amended with residues. }\end{array}$ & Belgium & 15 \\
\hline $\begin{array}{l}\text { Hordeum vulgare } \mathrm{L} . \\
\text { Pennisetum glaucum } \mathrm{L} . \\
\text { Beta vulgaris }\end{array}$ & $\begin{array}{l}\text { Roots became smaller in size, with deformity and inefficacy of nutrient } \\
\text { uptake. However, it may increase water use efficiency. Plants tend to } \\
\text { induce higher stomata resistance. }\end{array}$ & $\begin{array}{l}\text { Central and } \\
\text { Eastern Europe }\end{array}$ & 41 \\
\hline Z. mays $\mathrm{L}$. & $\begin{array}{l}\text { Produced lesser shoot elongation }(27.1 \%) \text { and leaf area }(67.8) \text {. There was } \\
\text { reduction in live root biomass production }(39.1 \%) \text {. }\end{array}$ & Nigeria & 42 \\
\hline $\begin{array}{l}\text { Lupinus angustifolius L., } \\
\text { B. napus ssp. Oleifera Hertzg. } \\
\text { and H. vulgare L. }\end{array}$ & $\begin{array}{l}\text { Affected root penetrance and showed that } L \text {. angustifolius } \text { L. and } \\
\text { B. napus ssp. Oleifera Hertzg. had better growth performance than } \\
\text { H. vulgare L. }\end{array}$ & Estonian & 43 \\
\hline Z. mays L., Sorghum spp. & $\begin{array}{l}\text { Produced lesser populations of macrofauna and earthworm. Application } \\
\text { of } 10 \mathrm{Mg} \text { axle weight under wet condition generated a negative change } \\
\text { in macrofauna ( } 78.57 \%) \text { and earthworm }(95.12 \%) \text { populations. }\end{array}$ & Australia & 44 \\
\hline Solanum tuberosum L., var. Calla & $\begin{array}{l}\text { Under fertilized condition, compacted soil produced higher } \mathrm{N}_{2} \mathrm{O} \text { emission } \\
\text { rate and thus influenced nitrogen uptake from the soil. }\end{array}$ & Germany & 45 \\
\hline Natural and mixed forest & Water infiltration rates were lowered by $70-99 \%$. & USA & 46 \\
\hline
\end{tabular}

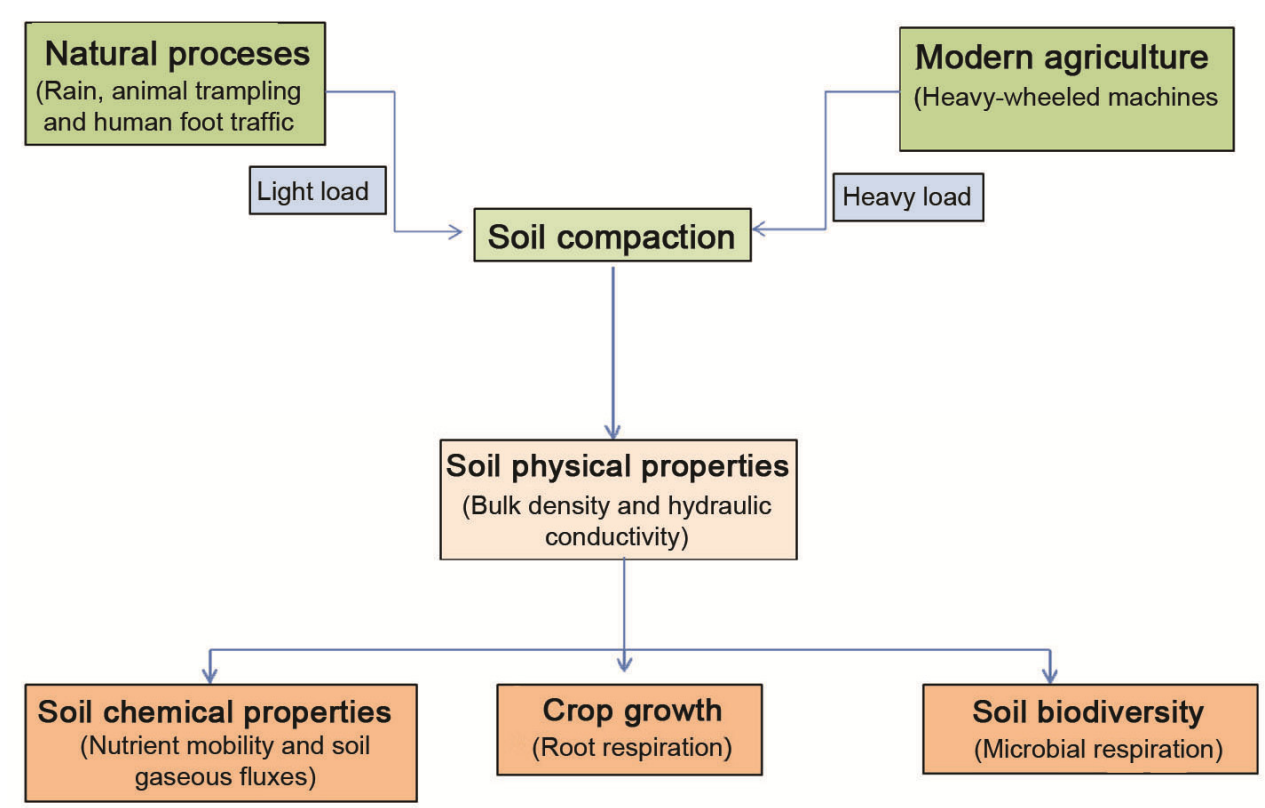

Figure 2. Soil compaction and its effects on soil physical properties with direct effects on soil chemical properties, crop growth and soil biodiversity.

root growth in root vegetables and delayed initiation of lateral roots for other vegetables. Forking and root splitting are common disorders in radish and carrot due to SC. Low oxygen concentration in the soil air affects the entire root system metabolism ${ }^{18}$. Decline in cellular oxygen concentration in root tissues causes root respiration to be replaced by anaerobic fermentation, resulting in reduced metabolic efficiency $^{18,19}$, which is undoubtedly unfavourable for shoot 
growth and overall yield by limiting water and nutrient uptake.

\section{Environmental impact of SC}

\section{Carbon dioxide}

Carbon (C) is absorbed by the plants in the form of carbon dioxide $\left(\mathrm{CO}_{2}\right)$ through photosynthesis. A fraction of this carbon is incorporated in the soil as organic matter, i.e. SOC, which in the long run can sequester this accumulated carbon. The sequestrated carbon is mineralized by microorganisms. Further, these microorganisms and root respiration release carbon into the atmosphere in the form of $\mathrm{CO}_{2}$.

Farm practices like harvesting and burning or removal of crop residues can reduce carbon input into the soil, while intensive tillage and intercultural operation increase the soil carbon output. It is known that SC lowers biomass production. As a consequence, the available soil carbon gradually declines. Recent research has indicated that $\mathrm{SC}$ reduces soil gas diffusivity and water drainage capacity, which create anaerobic conditions and adversely increase microbial respiration ${ }^{20}$. CTF reduces trafficinduced compaction in crop growth zone and reduces $\mathrm{CO}_{2}$ fluxes from the soil.

\section{Methane}

Methane $\left(\mathrm{CH}_{4}\right)$ is more powerful (28 times more potent than $\mathrm{CO}_{2}$ ) in contributing towards the greenhouse effect $(100 \text {-year time horizon })^{21}$. Based on the availability of oxygen, there is a source and sink relationship in $\mathrm{CH}_{4}$ and $\mathrm{CO}_{2}$. Agricultural soils under anaerobic conditions act as a source of $\mathrm{CH}_{4}$ (i.e. organic $\mathrm{C}$ is decomposed to $\mathrm{CH}_{4}$ ), while under aerobic conditions they act as a sink (i.e. $\mathrm{CH}_{4}$ is oxidized to $\mathrm{CO}_{2}$ and other compounds) ${ }^{20}$. SC creates anaerobic conditions, which increase $\mathrm{CH}_{4}$ production and limit oxidation of $\mathrm{CH}_{4}$ into $\mathrm{CO}_{2}$, and significantly increase greenhouse effects ${ }^{22}$. Production of rice, the widely grown cereal crop, is considered as one of the

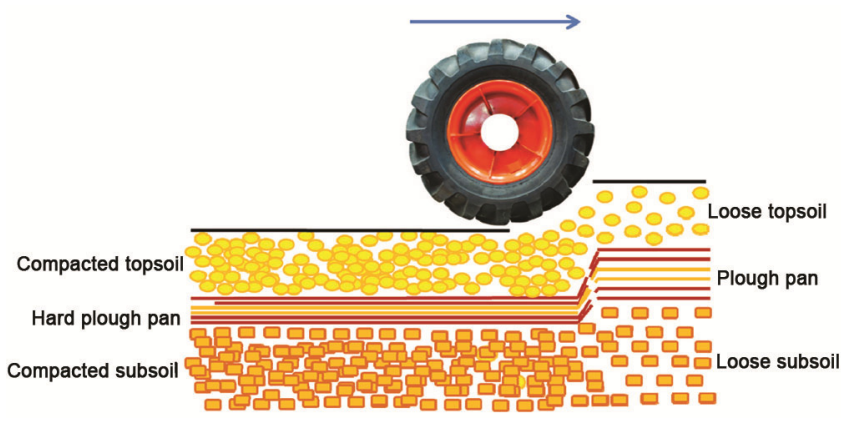

Figure 3. Effect of heavy vehicle-wheels in different soil layers. main sources of greenhouse gas emission from agricultural fields mainly due to puddling, which creates anoxic environment favourable for methane emission ${ }^{23}$. Vermeulen and Mosquera ${ }^{24}$ implemented partial CTF and after five years of practice, they found increased $\mathrm{CH}_{4}$ absorption in the range from $372 \%$ to $2100 \%$ (for small absolute emission values) when compared with RTF in spinach and carrot (Table 2).

\section{Nitrous oxide, ammonia and atmospheric nitrogen}

Nitrous oxide $\left(\mathrm{N}_{2} \mathrm{O}\right)$ is more powerful (265 times than $\left.\mathrm{CO}_{2}\right)$ in enhancing the greenhouse effect (100-year time horizon $)^{21}$. In agricultural soils, $\mathrm{N}_{2} \mathrm{O}$ emission takes place as a result of microbial transformation of ammonium $\left(\mathrm{NH}_{4}^{+}\right)$through the nitrification and denitrification processes. SC enhances anaerobic conditions, which promote denitrification, and consequently increase the production of $\mathrm{N}_{2} \mathrm{O}^{25,26}$. In addition, $\mathrm{SC}$, decreases the root accessibility to nutrients and thus enhances further nutrient $\operatorname{loss}^{27}$. The reduced soil gas diffusivity enhanced by $\mathrm{SC}$ increases the retention time of $\mathrm{N}_{2} \mathrm{O}$ in the soil which augments the denitrification process. Besides $\mathrm{N}_{2} \mathrm{O}$ and nitrogen $\left(\mathrm{N}_{2}\right)$, SC also increases ammonia $\left(\mathrm{NH}_{3}\right)$ emissions due to reduced soil hydraulic conductivity ${ }^{28}$. The emitted $\mathrm{NH}_{3}$ can precipitate on soil and water causing eutrophication (i.e. hypernutrification: pollution of ecosystems by nutrients), which leads to loss of aquatic biodiversity ${ }^{29,30}$.

\section{Benefits of CTF for vegetable production}

Reducing trafficked areas using CTF is a potential management tool to alleviate the problems associated with $\mathrm{SC}^{31}$. Unlike cereals, vegetable crops require more intercultural operations and staggered multiple harvesting. Additionally, a number of vegetables are grown to dry maturity, and supply schedules are demanding; harvest usually occurs when soil moisture conditions are ideal for compaction. All these technical hitches forced the vegetable industry to adopt CTF in some of the developed nations. The production of hand-harvested vegetable crops (e.g. lettuce, cucurbits, etc.) is well suited to the use of permanent bed, controlled traffic production systems.

Table 2. Soil $\mathrm{CH}_{4}$ fluxes and $\mathrm{N}_{2} \mathrm{O}$ emissions in control traffic farming (CTF) and random traffic farming (RTF)

\begin{tabular}{llrr}
\hline & & Spinach & Carrot \\
\hline $\mathrm{CH}_{4}$ fluxes $\left(\mathrm{CH}_{4} \mathrm{ha}^{-1} \mathrm{day}^{-1}\right)$ & $\mathrm{CTF}^{\mathrm{P}}$ & $-11.0^{\mathrm{b}}$ & $-11.8^{\mathrm{b}}$ \\
& $\mathrm{RTF}$ & $-0.5^{\mathrm{a}}$ & $-2.5^{\mathrm{a}}$ \\
& $\mathrm{CTF}_{2} \mathrm{O}$ emissions $\left(\mathrm{N}_{2} \mathrm{O} \mathrm{ha}\right.$ & $123.2^{\mathrm{b}}$ & $80.4^{\mathrm{b}}$ \\
& $\mathrm{RTF}$ & $225.6^{\mathrm{a}}$ & $130.4^{\mathrm{a}}$ \\
\hline
\end{tabular}

Source: Vermeulen and Mosquera ${ }^{24}$. 
In such a situation, the main issues to be considered are the dimensional integration of machinery appropriate to particular vegetable crops and maintenance equipment to maintain the integrity of wheel tracks and beds, and farm layout to ensure adequate drainage and improve paddock access in wet conditions. Furthermore, studies on CTF specify a range of direct and indirect effects (Figure 4), that include the following points ${ }^{4,32,33}$.

- Seasonal CTF helped in the improvement of crop yield by $31 \%, 35 \%$ and $10 \%$ for Pisum sativum L., Spinacea oleracea L. and Allium cepa L. respectively ${ }^{24}$.

- Adoption of CTF limits the compacted area to less than $15 \%$ for permanent wheel tracks, compared to more than $50 \%$ in RTF. CTF reduces traffic-induced $\mathrm{SC}$, improves physical properties of soil, plant available water, and facilitates root respiration and ultimately overall crop production, while potentially decreasing soil erosion, run-off and displacement of nutrients and agriculturally important chemicals ${ }^{34,35}$.

- CTF system separates the traffic zone, which results in the smooth functioning of tractors or heavy machinery, and also improves the working life of tractors, ensuring lower capital replacement costs.

- The CTF system reduces input over usage (fertilizers, fuel, seeds and chemicals). It was reported that fuel cost is reduced up to $50 \%$ and spraying cost by up to $10 \%$ (ref. 35), The adoption of CTF can save Rs 6000/ha from input $\operatorname{cost}^{36}$.

- Introduction of precision agriculture technologies such as variable rate technology, zone mapping, other sensor-based technologies and shielded spraying can be easy when CTF systems are already in use $\mathrm{s}^{37}$.

- Compaction of traffic zone improves the timeliness of culture practices like sowing, fertilization and weeding as better traction allows machinery to enter paddocks sooner in wet fields after heavy rainfall ${ }^{38}$.

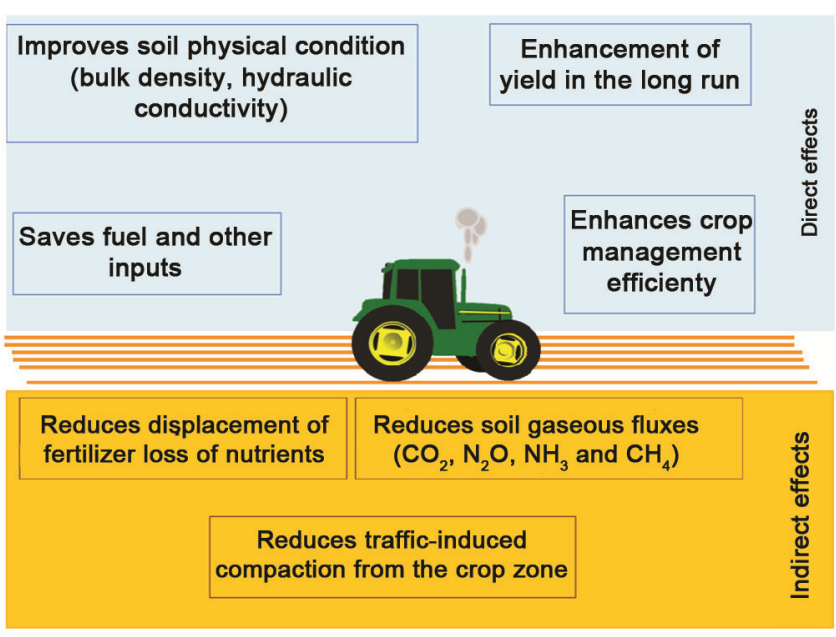

Figure 4. Direct and indirect effects of controlled traffic farming.
- CTF also tends to increase the beneficial soil microbial communities via favouring the microclimate of the soil ${ }^{39}$.

\section{Current status of CTF in India and adoption possibilities}

The concept of CTF is not new but for a country like India, where majority of land is fragmented and dominated by small and marginal farmers with diversified cropping practices, its adoption is difficult. Big farmers holding large land area at a stretch can be the innovators in the adoption process. Presently, the share of big farmers who use CTF for their crop production fields may be $<1 \%$. Currently, the acreage is not even more than 10,000/ha, which is negligible for a large agriculture-based country like India. Therefore, there is a huge scope for this practice in India.

Adoption of CTF is beneficial for farmers, be it economic or ecosystem sustainability. The adoption of this method requires harmony between integrated extension effort, awareness building and policy interventions, beside a strong research-based data resource across crops and agroclimatic zones for convincing the growers and policy makers at the local level. Above all, it needs to mention that no matter how good the technology is; it does not diffuse without any effort. Integrated approach has always been beneficial with regard to such novel technology dissemination. Participation of adopters, engagement of organizations in research extension continuum as well as Government policy support are important for such kinds of technology, where the benefit is not immediately and directly seen. Definitely, the farmers can raise their concerns about $15 \%$ of their lands accounted for traffic movement as no crop can be cultivated in this area. This may increase the chances of rejection of the CTF technology by majority of small and marginal farmers. The extension agents can convince the farmers by demonstrating the better yield potential from rest of the $85 \%$ undisturbed land area. Environmental benefits too are not visible apparently, which need sensitization through field functionaries working at the village level. Adoption of CTF requires a set of practices, which are crucial for harnessing the benefits, like hard wheel tract for tractor running, and only soft beds for crops. No wheel should enter into the crop zone. It has been seen that wide tracks, wide implements and narrow tyres deliver efficiency and effectiveness to farm operations. A clear-cut machinery plan must be chosen accordingly. CTF works better in zero tillage system. Adopters of zero tillage can also be encouraged to follow CTF in case of cereals. Here innovative training modules, such as training of tractor drivers under the Skill India' programme can be promoted. In addition, the other modern approaches like CTF, zero tillage, use of combined harvester, straw 
rollers, etc. can be covered under skill training. Presently, there is no provision for training of tractor drivers in India. Proper training of tractor drivers can save a lot of farmer inputs. The custom hiring centres and agribusiness centres in villages operating heavy machinery in agricultural fields should also be encouraged to appoint only trained drivers to perform field operations. Skill development in the farming sector needs a planned and focused approach. Recently, the national policy on skill development has also emphasized the same, which needs further strengthening. Moreover, the grassroots organizations engaged in extension activities must be involved in this process. Mainstreaming the institutional innovations to bring about desirable behavioural changes in the farming community is essential to achieve the overall success of $\mathrm{CTF}$, like any other evolving technology.

\section{Conclusion}

This article summarizes the advantageous of CTF over conventional system. However, the adoption of CTF sill required modification in different farm machinery involved in the production system. One of the main advantages of CTF is the reduction in the number of tillage operations. The effect of CTF on soil physical properties is evident through beneficial changes in soil bulk density, infiltration and soil resistance, and enhancement in soil fertility through improved carbon storage in the soil. While writing this article, India-based studies were hard to find. Under Indian conditions, more research is needed such as: (i) performance studies of vegetables and other horticultural crops under CTF in different soil and agroclimatic zones; (ii) quantification of environmental and economic impacts due to adoption of CTF; (iii) farm mechanization-related adaptive research in Indian soil conditions; (iv) farm innovations at farmers' field-related studies, and many more. Though there has been rapid advancement in farm mechanization in the Indian agricultural system, still Indian farming communities have mainly relied on RTF. Given the burning issue of farm profit maximization (doubling farmers' income) and environmental sustainability, it is the high time to realize the importance of CTF in Indian condition with solid weightage on conservation agriculture mandates.

1. Meredith, H. L. and Patrick Jr, W. H., Effects of SC on subsoil root penetration and physical properties of three soils in Louisiana. Agron. J., 1961, 53(3), 163-167.

2. Russell, R. S. and Goss, M. J., Physical aspects of soil fertility. The response of roots to mechanical impedance. Neth. J. Agric. Sci., 1974, 22(1), 305-318.

3. Taylor, J. H., Benefits of permanent traffic lanes in a controlled traffic crop production system. Soil Till. Res., 1983, 3, 385-395.

4. Li, Y. X., Tullberg, J. N., Freebairn, D. M. and Li, H. W., Functional relationships between soil water infiltration and wheeling and rainfall energy. Soil Till. Res., 104(1), 156-163.
5. Taylor, J. H., Reduction of traffic induced soil compactionspecial issue. Soil Till. Res., 1992, 24, 301-302.

6. McPhee, J. E., Aird, P. L., Hardie, M. A. and Corkrey, S. R., The effect of controlled traffic on soil physical properties and tillage requirements for vegetable production. Soil Till. Res., 2015, 149, 33-45.

7. ICAR-IASRI, Agricultural Research Data Book, ICAR-Indian Agricultural Statistics Research Institute, New Delhi, 2019, pp. 253-254.

8. Wolfe, D. W., Topoleski, D. T., Gundersheim, N. A. and Ingall, B. A., Growth and yield sensitivity of four vegetable crops to SC. J. Am. Soc. Hortic. Sci., 1995, 120(6), 956-963.

9. Abu-Hamdeh, N. H., Compaction and sub-soiling effects on corn growth and soil bulk density. Soil Sci. Soc. Am. J., 2003, 67(4), 1213-1219.

10. SSSA, Glossary of soil science terms. Soil Science Society of America, Madison, USA, 1996.

11. Hakansson, I., Voorhees, W. B. and Riley, H., Vehicle and wheel factors influencing SC and crop response in different traffic regimes. Soil Till. Res., 1988, 11(3-4), 239-282.

12. Unger, P. W. and Kaspar, T. C., SC and root growth: a review. Agron. J., 1994, 86(5), 759-766.

13. Orzolek, M. D., Establishment of vegetables in the field. HortTechnol., 1991, 1(1), 78-81.

14. Allmaras, R. P., Kraft, J. M. and Miller, D. E., Effects of SC and incorporated crop residues on root health. Annu. Rev. Phytopathol., 1988, 26(1), 219-243.

15. De Neve, S. and Hofman, G., Influence of SC on carbon and nitrogen mineralization of soil organic matter and crop residues. Biol. Fertil. Soils, 2000, 30(5-6), 544-549.

16. Bengough, A. G., McKenzie, B. M., Hallett, P. D. and Valentine, T. A., Root elongation, water stress, and mechanical impedance: a review of limiting stresses and beneficial root tip traits. J. Exp. Bot., 2011, 62(1), 59-68; https://doi.org/10.1093/jxb/erq350.

17. Young, I. M., Montagu, K., Conroy, J. and Bengough, A. G., Mechanical impedance of root growth directly reduces leaf elongation rates of cereals. New Phytol., 1997, 135(4), 613-619; https:// doi.org/10.1046/j.1469-8137.1997.00693.x.

18. Fukao, T. and Bailey-Serres, J., Plant responses to hypoxia - is survival a balancing act? Trends Plant Sci., 2004, 9(9), 449-456; https://doi.org/10.1016/j.tplants.2004.07.005.

19. Colombi, T. and Keller, T., Developing strategies to recover crop productivity after SC - a plant eco-physiological perspective. Soil Till. Res., 2019, 191, 156-161.

20. Gasso, V., Sørensen, C. A., Oudshoorn, F. W. and Green, O., Controlled traffic farming: a review of the environmental impacts. Eur. J. Agron., 2013, 48, 66-73.

21. IPCC, Fifth Assessment Report, Climate Change 2014, United Nations Inter-governmental Panel on Climate Change, 2014.

22. Sitaula, B. K., Hansen, S., Sitaula, J. I. B. and Bakken, L. R., Methane oxidation potentials and fluxes in agricultural soil: effects of fertilisation and SC. Biogeochemistry, 2000, 48(3), 323-339.

23. Nemecek, T. and Kagi, T., Life cycle inventories of agricultural production systems. Report No. 15, Ecoinvent: Zurich, Switzerland, 2007.

24. Vermeulen, G. D. and Mosquera, J., Soil, crop and emission responses to seasonal-controlled traffic in organic vegetable farming on loam soil. Soil Till. Res., 2009, 102(1), 126-134.

25. van Groenigen, J. W., Kuikman, P. J., de Groot, W. J. M. and Velthof, G. L., Nitrous oxide emission from urine-treated soil as influenced by urine composition and soil physical conditions. Soil Biol. Biochem., 2005, 37(3), 463-473.

26. Yamulki, S. and Jarvis, S. C., Short-term effects of tillage and compaction on nitrous oxide, nitric oxide, nitrogen dioxide, methane and carbon dioxide fluxes from grassland. Biol. Fertil. Soils, 2002, 36(3), 224-231. 
27. Wolkowski, R. P., Relationship between wheel-traffic-induced SC, nutrient availability, and crop growth - a review. J. Prod. Agric., 1990, 3(4), 460-469.

28. Braunack, M. V. and McGarry, D., Traffic control and tillage strategies for harvesting and planting of sugarcane (Saccharum officinarum) in Australia. Soil Till. Res., 2006, 89(1), 86-102.

29. FAO, Global estimates of gaseous emissions of $\mathrm{NH}_{3}, \mathrm{NO}$ and $\mathrm{N}_{2} \mathrm{O}$ from agricultural land. Food and Agriculture Organization of the United Nations, Rome, Italy, 2001.

30. Smith, S. J., Sharpley, A. N., Naney, J. W., Berg, W. A. and Jones, O. R., Water-quality impacts associated with wheat culture in the Southern Plains. J. Environ. Qual., 1991, 20(1), 244-249.

31. Johansen, T. J., Thomsen, M. G., Løes, A. K. and Riley, H., Root development in potato and carrot crops-influences of SC. Acta Agric. Scand. B-Soil Plant Sci., 2015, 65(2), 182-192.

32. Jochinke, D. C., Noonon, B. J., Waschsmann, N. G. and Norton, R. M., The adoption of precision agriculture in an Australian broadacre cropping system - challenges and opportunities. Field Crops Res., 2007, 104(1-3), 68-76.

33. Kingwell, R. and Fuchsbichler, A., The whole-farm benefits of controlled traffic farming: an Australian appraisal. Agric. Syst., 2011, 104(7), 513-521.

34. Raper, R. L., Agricultural traffic impacts on soil. J. Merramech., 2005, 42(3-4), 259-280.

35. Tullberg, J. N., Yule, D. F. and McGarry, D., Controlled traffic farming - from research to adoption in Australia. Soil Till. Res., 2007, 97(2), 272-281.

36. Webb, B., Blackwell, P., Reithmuller, G. and Lemon, J., Tramline Farming Systems: Technical Manual. Department of Agriculture and Food, Western Australia, Perth. Bulletin 460-7, 2004.

37. Robertson, M. J., Carberry, P. and Brennan, L., The economic benefits of precision agriculture: case studies from Australian grain farms. CSIRO, Canberra, Australia, 2007.
38. Rainbow, R., Getting into precision agriculture - the basics. Precision AgNews Winter 2003, Southern Precision Agriculture Association, Mildura Victoria, Australia, 2003.

39. Rodgers, D., McPhee, J., Aird, P. and Corkrey, R., Soil arthropod responses to controlled traffic in vegetable production. Soil Till. Res., 2018, 180, 154-163.

40. Chen, G. and Weil, R. R., Penetration of cover crop roots through compacted soils. Plant Soil, 2010, 331(1-2), 31-43.

41. Lipiec, J., Medvedev, V. V., Birkas, M., Dumitru, E., Lyndina, T. E., Rousseva, S. and Fulajtar, E., Effect of SC on root growth and crop yield in Central and Eastern Europe. Int. Agrophys., 2003, 17(2), 61-70.

42. Olubanjo, O. O. and Yessoufou, M. A., Effect of SC on the growth and nutrient uptake of Zea Mays L. Sustain. Agric. Res., 2019, 8(2), 46-54

43. Trükmann, K., Reintam, E., Kuht, J., Nugis, E. and Edesi, L., Effect of SC on growth of narrow-leafed lupine, oilseed rape and spring barley on sandy loam soil. Agron. Res., 2008, 6(1), 101-108.

44. Radford, B. J., Wilson-Rummenie, A. C., Simpson, G. B., Bell, K. L. and Ferguson, M. A., Compacted soil affects soil macrofauna populations in a semi-arid environment in central Queensland. Soil Biol. Biochem., 2001, 33(12-13), 1869-1872.

45. Ruser, R., Flessa, H., Russow, R., Schmidt, G., Buegger, F. and Munch, J. C., Emission of $\mathrm{N}_{2} \mathrm{O}, \mathrm{N}_{2}$ and $\mathrm{CO}_{2}$ from soil fertilized with nitrate: effect of compaction, soil moisture and rewetting. Soil Biol. Biochem., 2006, 38(2), 263-274.

46. Gregory, J. H., Dukes, M. D., Jones, P. H. and Miller, G. L., Effect of urban SC on infiltration rate. J. Soil Water Conserv., 2006, 61(3), 117-124.

Received 16 April 2020; accepted 18 September 2020

doi: $10.18520 / \mathrm{cs} / \mathrm{v} 119 / \mathrm{i} 11 / 1760-1766$ 